\title{
Bio-Flotation of Egyptian Siliceous Phosphate Ore Using Bacillus Cereus
}

\author{
Samah S.Abdallah ${ }^{1}$, E. H. El-shatoury ${ }^{2}$, Nagui A. Abdel-khalek ${ }^{1}$, Mohamed A. Youssef ${ }^{1}$, \\ Khaled A. Selim ${ }^{1}$, M. K. Ibrahim², Samah M. Elsayed ${ }^{1}$ \\ ${ }^{1}$ Central Metallurgical Research \& Development Institute, CMRDI \\ Helwan, Egypt, Cairo \\ samahsaleh86@cmrdi.sci.eg; naguialy@gmail.com; myousef19461@yahoo.com; k2selem1@gmail.com; \\ samahelsayed86@yahoo.com \\ ${ }^{2}$ Ain Shams University \\ Abbasia, Cairo, Egypt \\ shatourye@ hotmail.com; kkkmohamed1@hotmai.com
}

\begin{abstract}
In recent years mining industry has been facing several problems that influence it. The former aspect compels the mining industry to process low grade ores, fine mineral particles and flotation tailings to produce material suitable for a global market. So it has become very important to develop appropriate and environmentally friendly technologies able to replace the conventional techniques used for the mineral beneficiation. The bio-beneficiation process using microbes adapted from the surface of the rock is the method for choice to removal of undesirable gangue minerals from the desired valuable phosphate (apatite) minerals. Through this study, a concentrate with $18.5 \% \mathrm{P}_{2} \mathrm{O}_{5}$ and $33.03 \%$ sio 2 has been obtained from a binary mixture having $11.65 \% \mathrm{P}_{2} \mathrm{O}_{5}$ and sio $40.98 \%$. On applying the optimum conditions on natural phosphate ore containing $21.89 \%$, a concentrate with $27.2 \% \mathrm{P}_{2} \mathrm{O}_{5}$ has been obtained on using bioflotation process with Bacillus cereus bacteria.
\end{abstract}

Keywords: Bacillus cereus, Phosphate, Bioflotation, Adsorption.

\section{Introduction}

Phosphate ore reserves in Egypt are present in three main localities namely; Nile valley, New Valley in western desert, and the Eastern Desert along the red sea coast. Currently, newly discovered phosphate ores are being mined from Nile valley areas mainly for exportation and partially for local production of fertilizers, phosphoric acid, and animal feed production. However, in exporting such ores, the mining companies export only the coarse fractions of the run of mine ores of high grade (over $\left.30 \% \mathrm{P}_{2} \mathrm{O}_{5}\right)$ while the fine fractions of low grade $\left(\sim 18-22 \% \mathrm{P}_{2} \mathrm{O}_{5}\right.$ content), for the time being, are rejected. This is because such fine fractions contain different gangue minerals (mainly silica). Because of the increasing world demand for phosphate, $\mathrm{P}_{2} \mathrm{O}_{5}$ content of the ore is gradually falling, and it is becoming an economical to mine and beneficiate many lower-grade deposits for production of phosphate fertilizers(1-4).

The surface characteristics of the separated minerals control the separation results in terms of achieving a good selectivity (5). The attachment of bacteria onto mineral surfaces was found to play an important role in improving the separation selectivity in flotation and flocculation. Several studies utilized the difference in surface properties between two minerals for selective attachment of bacteria(6). However, limited studies focused on the altering the surface properties by the bacterial adsorption. The adhesion of Bacillus subtilis and Mycobacterium phlei onto dolomite and apatite was studied by sorption measurements and scanning electron microscopy, It was found that both B. subtilis and M. phlei adhered to dolomite more readily than onto apatite at acidic and near neutral $\mathrm{pH}$ values(7). Two strains of bacteria namely (Corynebacterium- diphtheriae-intermedius, Pseudomonas Aeruginosa) were used to modify the dolomite and phosphate surfaces and enhance the conventional flotation using amphoteric collector(8).

Phosphorus is an important plant nutrient after nitrogen. Phosphorus availability is low in soil because of its fixation as insoluble phosphate(9-10). The deficiency of phosphorus in soil adversely affects plant growth and direct application of phosphate rock is not effective without previous treatment. In the same time, applying low quality fertilizers might contain considerable concentrations of harmful elements which will be transferred to the animal and human beings. In this paper, the amenability of upgrading natural Egyptian phosphate rock has been tested using Bacillus cereus bacteria via bio-flotation process. 


\section{Experimental Techniques}

\subsection{Materials}

Samples of single minerals of silica $\left(\mathrm{SiO}_{2}\right)$, apatite $\left(\mathrm{P}_{2} \mathrm{O}_{5}\right)$ with purity $(99.9 \%)$ examined using XRF. The -200 mesh fractions were used in adsorption and flotation studies. Analytical grade $\mathrm{HCl}$ and $\mathrm{NaOH}$, from Aldrich, were used for $\mathrm{pH}$ regulations, Natural phosphate ore was collected from Nile valley Locality, Egypt.

\subsection{Methods}

\subsubsection{Bacterial Isolation and Maintaince}

$28 \mathrm{gm}$ of bacterial medium consisting of peptone, beef extract, $\mathrm{NaCl}$ and mycological Agar was dissolved in $1 \mathrm{~L}$ of bi-distilled water. The solution was autoclaved at $120 \mathrm{c}^{\circ}$, cooled and poured in Petri dish for solidification. After that, about $0.5 \mathrm{gm}$ of sample was suspended in $100 \mathrm{ml}$ of bi-distilled water; $1 \mathrm{ml}$ of solution was poured on agar plate and then incubated at a temperature of $37 \mathrm{c}^{\circ}$ for $24-48$ hours. The bacterial isolates were grown in a nutrient broth and incubated for $24 \mathrm{hr}$ at $37 \mathrm{c}^{\circ}$. The bacterial population was determined by measuring the turbidity or the optical density of the bacterial suspension using a UV visible spectrophotometer (Lambda 3B, Perkin- Elmer). The turbidity for cell suspension is measured at a wavelength of $550 \mu \mathrm{m}$ against nutrient broth medium as reference, at which the 0.01 reading is equivalent to 106 cells $\mathrm{mL}^{-1}$.

\subsubsection{Measuring Selectivity of Bacillus Cereus to Mineral Surface}

A laser particle size analyzer (FRITSCH Model Analyst 22) was employed for measuring size analysis of single minerals before and after treatment with bacteria. Fixed volume $10 \mathrm{ml}$ of Bacillus cereus was conditioned with one gram of each mineral for 60 minutes before recording the change in size distribution.

\subsubsection{Chemical Analysis}

Routine chemical analysis of samples was conducted using standard methods. Phosphorus content was determined using spectroscopic technique. Meanwhile complete chemical analysis of samples was conducted using "Philips" X-ray fluorescence (XRF).

\subsubsection{Zeta Potential Measurements}

A laser Zeta Meter 'Malvern Instruments Model Zeta Sizer 2000' was used for zeta potential measurements. $0.05 \mathrm{~g}$ of ground sample was placed in $50 \mathrm{ml}$ double distilled water with definite concentration of the bacterial isolate at fixed ionic strength of $2 \times 10^{-2} \mathrm{M} \mathrm{NaCl}$. NaOH and $\mathrm{HCL}$ were used as $\mathrm{pH}$ modifiers. The suspension was conditioned for 60 minutes during which the $\mathrm{pH}$ was adjusted. After shaking, the equilibrium $\mathrm{pH}$ was recorded. It was then allowed to settle for $3 \mathrm{~min}$, after which $10 \mathrm{ml}$ of the supernatant was transferred into a standard cuvette for zeta potential measurement. Solution temperature was maintained at $\left(25 \mathrm{o}^{\mathrm{C}} \pm 2\right)$. Five measurements were taken and the average was reported as the measured zeta potential. (11)

\subsubsection{Adsorption Measurements}

The adsorption of bacterial isolate on the mineral surface was determined by adding $1 \mathrm{~g}$ dry sample of silica or apatite to the bacterial solutions $\left(50 \mathrm{~cm}^{3}\right)$ in a $100 \mathrm{~cm}^{3}$ volumetric flask. The mixture was shacked for 15 minutes using a shaker (Model JANKE \& KUNKEL Type VX10). The $\mathrm{pH}$ was adjusted to the desired values using $\mathrm{HCl}$ and $\mathrm{NaOH}$, after which the samples were filtered by filter paper then using spectrophotometer to measure the adsorption of bacterial isolate to mineral surface. (12)

\subsubsection{FTIR Measurements}

Infrared absorption spectra were recorded for apatite; silica and bacteria before and after interactions using Fourier Transform Infrared Spectrometer (Model FT/IR 6300). After interaction with bacteria, the mineral samples were thoroughly washed using double distilled water and vacuum dried. The $\mathrm{KBr}$ pellet technique was used to record the spectra (13).

\subsubsection{Flotation Experiments}

A series of bench-scale flotation experiments were conducted using a modified Halimond tube with $150 \mathrm{ml}$ capacity. In carrying out these flotation experiments one gram (of single minerals or their binary mixture as well as natural ore) were conditioned at the pre-determined optimum conditions of $\mathrm{pH} \mathrm{3}$, concentration of bacterial isolate of $10 \mathrm{ml}(9 \mathrm{x}$ $10^{10}$ cells $\mathrm{mL}^{-1}$ ) and conditioning time 10 minutes using a horizontal shaker. The $\mathrm{pH}$ was adjusted with dilute solutions 
of $\mathrm{NaOH}$ and $\mathrm{HCl}$. The flotation was conducted for 5 minutes at air follow rate of $0.7 \mathrm{~cm}^{-3} / \mathrm{min}$. Both floated and sink fractions were collected, dried, weighted, and analysed (14).

\section{Results and Discussion}

\subsection{Selectivity of Microorganism to Minerals' Surfaces}

The change in size distribution of single pure mineral samples, silica and apatite after its treatment with Bacillus cereus was taken as a measure for the selectivity. Successful adsorption of the bacterial isolate will cause, therefore, a degree of aggregation (or dispersion) for mineral particles leading to a change in their size distribution. This technique was successfully used to screen different microorganisms for selective adhesion onto apatite or silicate surfaces. The results obtained in Figures 1 and 2 as well as table 1 show different degrees of variation in the size distribution of samples after their treatment with bacteria which indicates the selectivity of Bacillus cereus to apatite rather than silica. Change of size of particle of apatite by treatment with Bacillus cereus from 12.29 to 9.74 with no change in particle size of silica.

Table 1: Change in the mean particle Size, d50 of single minerals after treatment with bacterial isolate.

\begin{tabular}{|c|c|c|c|c|}
\hline \multirow{3}{*}{ Bacterial isolate } & \multicolumn{4}{|c|}{ Particle size $(\mathrm{d} 50)$} \\
\cline { 2 - 5 } & \multicolumn{2}{|c|}{ Apatite, $(\mathrm{d} 50) \mathrm{m}$} & \multicolumn{2}{|c|}{ Silica, (d50) m } \\
\cline { 2 - 5 } & $\begin{array}{c}\text { Before } \\
\text { treatment }\end{array}$ & $\begin{array}{c}\text { After } \\
\text { treatment }\end{array}$ & $\begin{array}{c}\text { Before } \\
\text { treatment }\end{array}$ & $\begin{array}{c}\text { After } \\
\text { treatment }\end{array}$ \\
\hline Bacillus cereus & 12.29 & 9.74 & 9.33 & 9.27 \\
\hline
\end{tabular}

This technique was successfully used to screen different bacterial isolates for selective adhesion onto apatite, dolomite, quartz $(15,16,18,17)$.

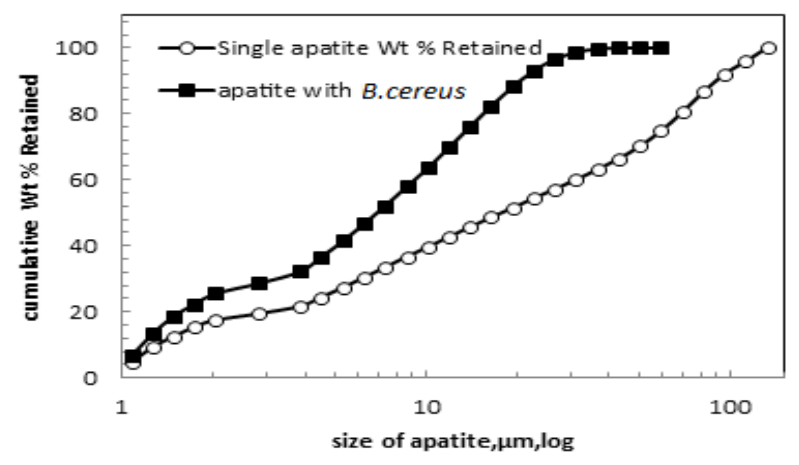

Fig. 1: Size distribution of apatite with Bacillus cereus.

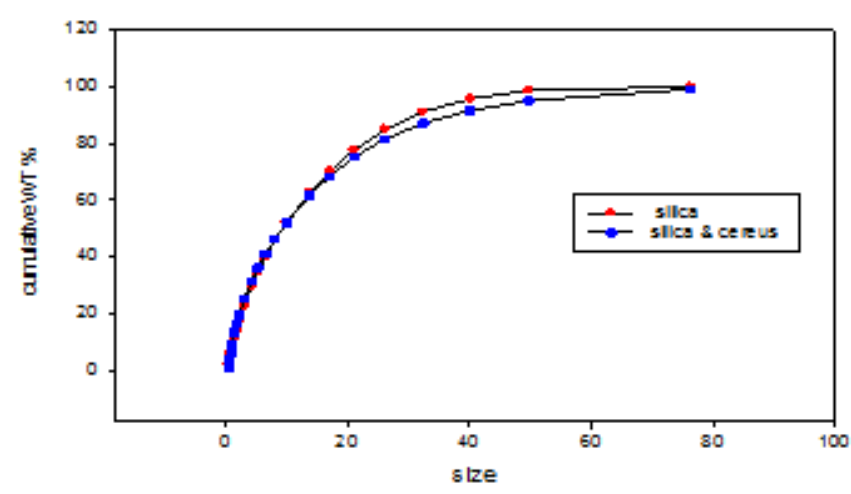

Fig. 2: Size distribution of silica with Bacillus cereus. 


\subsection{Bacterial Adhesion onto Minerals' Surfaces}

Figure 3 shows the adhesion of bacteria onto the surface of single minerals over a wide range of $\mathrm{pH}$ (1-12). The results showed that, the separation between apatite and silica could be achieved in $\mathrm{pH}$ between 6-9. Lower and higher $\mathrm{pH}$ values resulted in less separation.

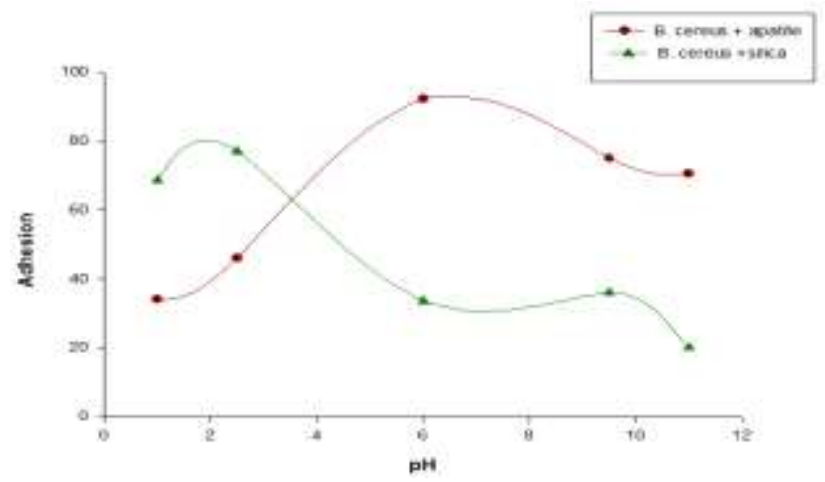

Fig. 3: Adhesion of Bacillus cereus onto Minerals'Surfaces.

(19) have provided an excellent review of the importance of bio-processing in mineral separation using different types of bacterial isolates. For example, attachment of Thiobacillus ferrooxidans on to various sulphide minerals and quartz having different surface properties has been studied (26). Similarly, the selective adsorption of T. ferrooxidans to pyrite has been reported (21). Mycobacterium phlei has been used for flocculation and flotation of several minerals including hematite $(19,24)$, apatite and dolomite (28), phosphates (25), kerogen (20) and coal(22.23,27). The differential adhesion of M. phlei on to different mineral surfaces has also been reported (23). The difference in surface properties between two minerals, i.e.hydrophobicity and surface charge were utilized for selective attachment of the microorganism, which in turn led to selective flotation or flocculation.

\subsection{Surface Properties of Single Minerals and Bacillus Cereus Bacteria}

Zeta potential of single mineral-bacteria system was studied. Measurement of zeta potential of Bacillus cereus alone as well as for each single mineral, apatite and silica, in absence and presence of bacteria has been performed, Figure 4 illustrates the zeta potential of the Bacillus cereus in which the values of zeta potential varied from (+15 to $-35 \mathrm{mv}$ ) over the entire range of $\mathrm{pH}(2.0-12)$. The iso-electric point (IEP) of bacteria is about at $\mathrm{pH}$ of 2.5 .

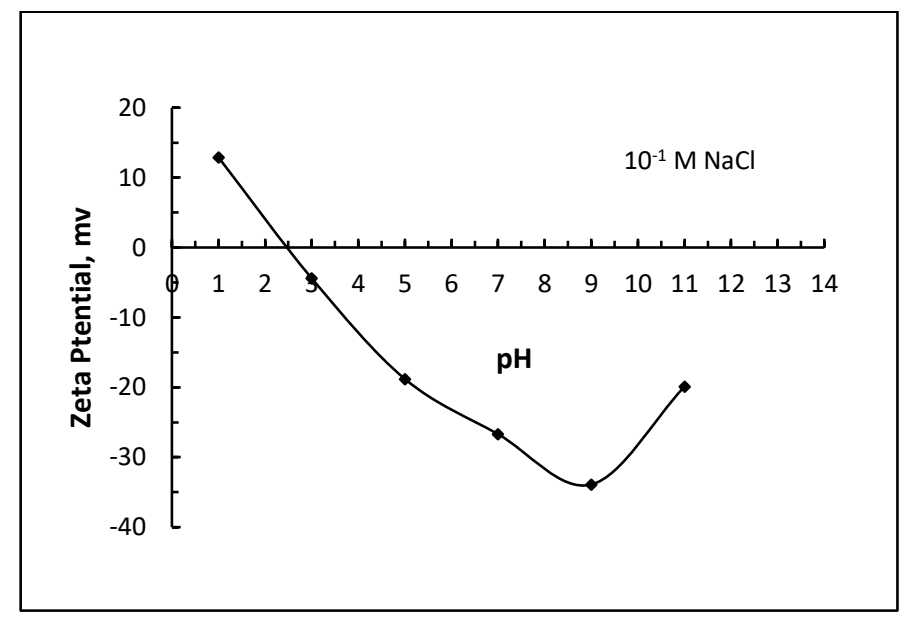

Fig. 4: Zeta potential of Bacillus cereus.

On the other hand, Fig.5 shows the zeta potential and hydrophobicity of bacterial isolate with apatite. The addition of bacteria to apatite resulted in decrease in negativity of it and increase in hydrophobicity of sample more over the isoelectric point of apatite was shifted from 4.8 to 1.8 by addition of Bacillus cereus. 


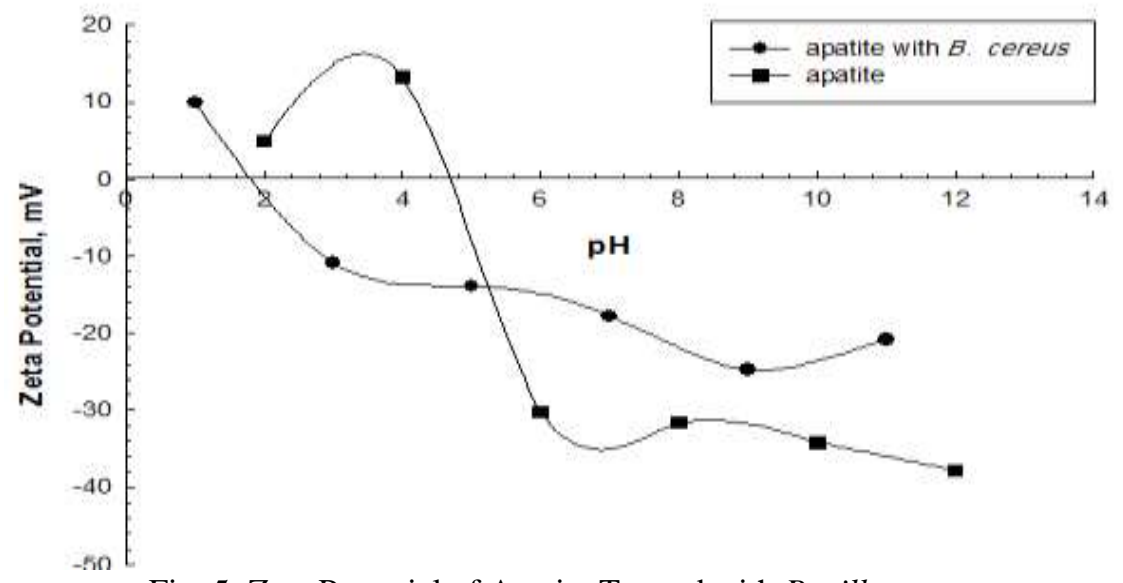

Fig. 5: Zeta Potential of Apatite Treated with Bacillus cereus.

Where in Fig.6, shows the zeta potential and hydrophobicity of bacterial isolate with silica. The addition of bacteria to silica resulted in decrease in negativity of it and increase in hydrophobicity in the $\mathrm{pH}$ range (6.5-12) of sample more over the isoelectric point of silica was shifted from 1.8 to 2 by addition of Bacillus cereus.

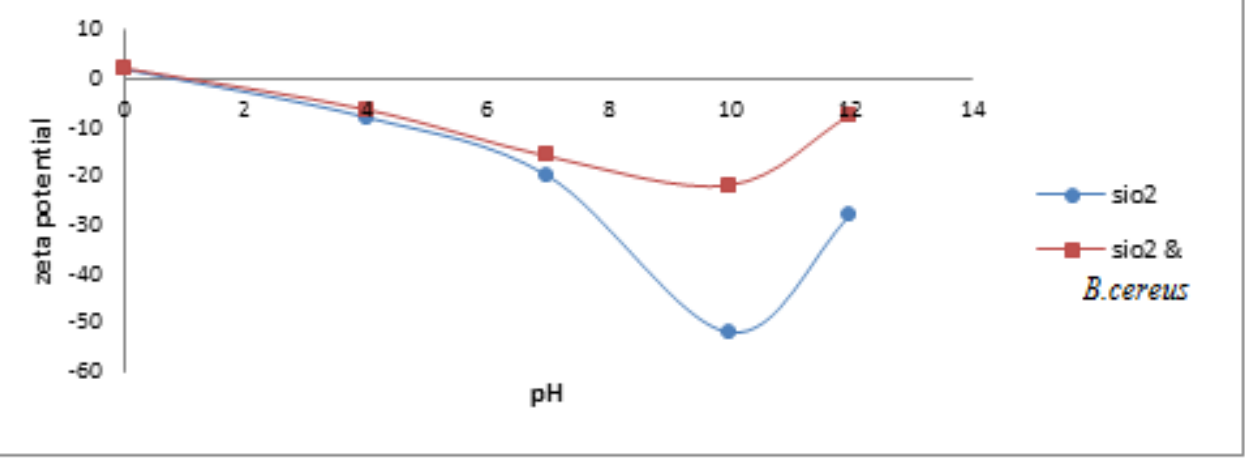

Fig. 6: Zeta Potential of silica Treated with Bacillus cereus.

(30) found that microbe-mineral interactions result in significant surface chemical changes on mineral surfaces. The manner in which different types of bacteria bring about such changes on the electro kinetic properties of quartz, kaolinite, hematite, calcite and corundum, with reference to influence of bacterial metabolite, bacterial protein and polysaccharides have been studied. For quartz, the measured zeta potentials were seen to be shifted in a more positive direction after interaction with bacterial metabolite, and protein. (20). In the mean time, (31) have mentioned that unlike the case with quartz and kaolinite, the effect of bacteria interaction on the surface chemical behavior of hematite, corundum and calcite was different in that the measured zeta potentials were observed to shift towards more negative values, both with metabolites and bio-polysaccharides (31).

\subsection{FTIR Measurements:}

To understand the role of interaction between mineral surface and Bacillus cereus, FTIR measurements were conducted for the bacteria and apatite. FTIR of bacteria showed the existence of $\mathrm{O}-\mathrm{H}, \mathrm{C}-\mathrm{C}, \mathrm{CH} 2, \mathrm{C}-\mathrm{O}, \mathrm{C}-\mathrm{N}$ and $\mathrm{C}=\mathrm{O}$ bands in decreasing order. These bands reflect the general organic structure of bacteria which are mainly composed of polysaccharides and lipids (protein). Polysaccharides are defined from their hydroxyl bands at $3600-3200 \mathrm{~cm}^{-1}$ and carboxyl group bands at $1210-1740 \mathrm{~cm}^{-1}$ whereas the protein is characterized by its amino group bands at $3460-3150$ $\mathrm{cm}^{-1}$ and $1650-1500 \mathrm{~cm}^{-1}$ respectively. 


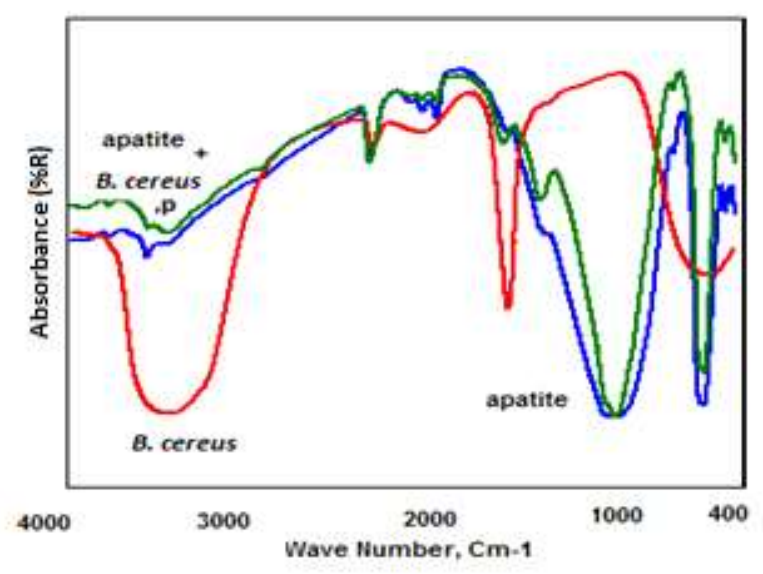

Fig. 7: FTIR for B. cereus, apatite and its treated surface with B. cereus.

\subsection{Bioflotation of Binary Mixtures}

The amenability of applying Bacillus cereus, to be used as the sole flotation reagent, to selectively separate silica and apatite from their binary mixtures was studied. The net results obtained at optimum operating conditions are shown in Table 2 and fig. 8.

Initial concentration of $\mathrm{P}_{2} \mathrm{O}_{5}$ and $\mathrm{SiO}_{2}$ was 11.56 and 40.89 respectively, using $10 \mathrm{ml}$ of bacteria for each $1 \mathrm{gm}$ of sample and at 10 minutes as conditioning time.

Table 2: Separation of silica from apatite in a binary mixture.

\begin{tabular}{|l|l|l|l|l|}
\hline $\mathrm{pH}$ & \multicolumn{2}{|l|}{ Float } & \multicolumn{2}{l|}{ Sink } \\
\hline & $\mathrm{P}_{2} \mathrm{O}_{5} \%$ & $\mathrm{SiO}_{2} \%$ & $\mathrm{P}_{2} \mathrm{O}_{5} \%$ & $\mathrm{SiO}_{2} \%$ \\
\hline 6.00 & 18.5 & 33.03 & 3.9 & 53 \\
\hline 9.50 & 13.23 & 33.61 & 8.5 & 49.5 \\
\hline
\end{tabular}

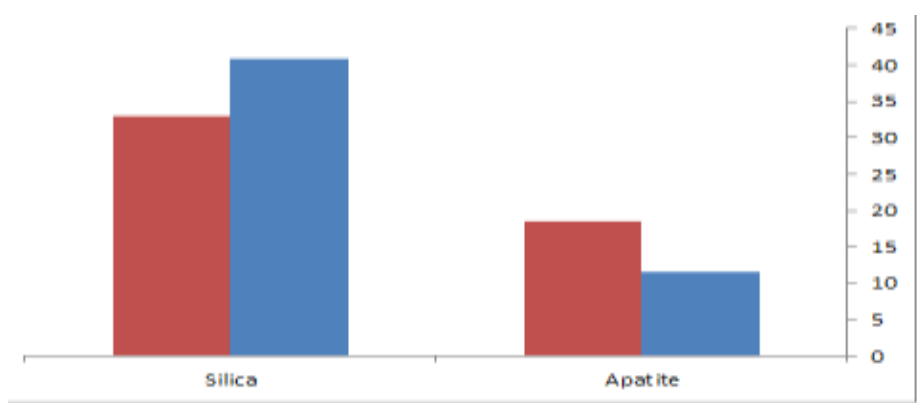

Fig. 8: Separation of silica from apatite in a binary mixture

On applying the procedure on a natural phosphate ore at optimum conditions, we succeeded on obtaining a concentrate with $27.2 \% \quad \mathrm{P}_{2} \mathrm{O}_{5}$ from a feed containing $21.89 \% \mathrm{P}_{2} \mathrm{O}_{5}$, table 3 and fig 9.

Table 3: Separation of silica from apatite in natural phosphate ore sample.

\begin{tabular}{|l|l|l|}
\hline $\mathrm{P}_{2} \mathrm{O}_{5} \%$ in ore & \multicolumn{2}{|c|}{21.89} \\
\hline & Float & Sink \\
\hline $\mathrm{P}_{2} \mathrm{O}_{5} \%$ in ore with Bacillus cereus at $\mathrm{pH} \mathrm{6-7.5}$ & 27.2 & 9.81 \\
\hline
\end{tabular}




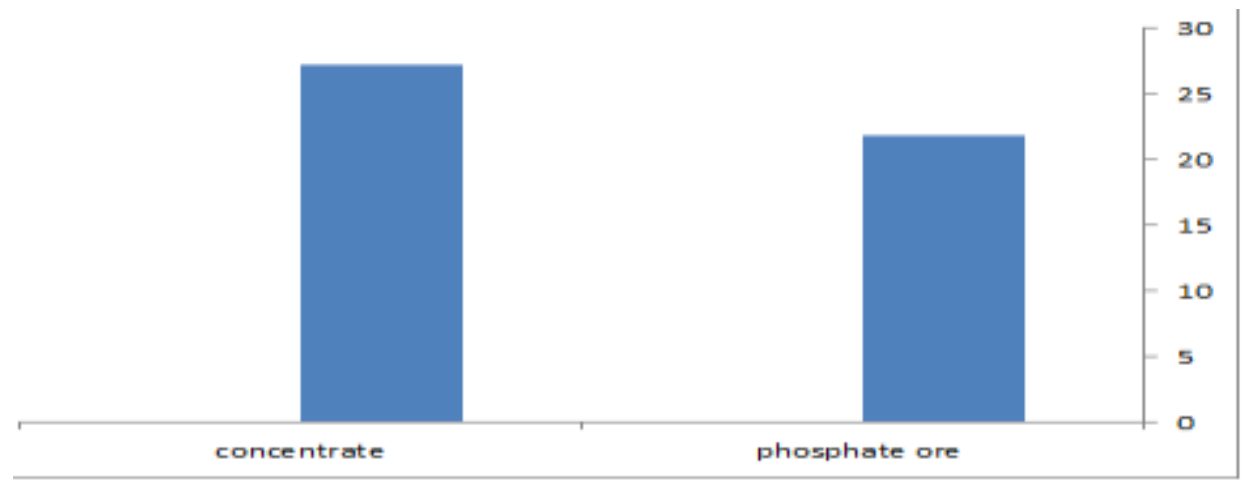

Fig. 9: Separation of silica from apatite in natural phosphate ore sample.

\section{Conclusion}

The results showed a strong interaction between Bacillus cereus bacteria and apatite surface. Adhesion, adsorption and zeta potential measurements showed a better affinity of Bacillus cereus to apatite mineral surface.

The selectivity of apatite flotation against silica was observed in the micro-flotation tests. The results show the potentiality for using Bacillus cereus bacteria as a sole flotation reagent where a concentrate containing $18.5 \% \mathrm{P}_{2} \mathrm{O}_{5}$ could be obtained from a mixture containing $11.56 \%$.

Applying the same conditions on flotation of the natural phosphate ore yielded a concentrate containing $27.2 \% \mathrm{P}_{2} \mathrm{O}_{5}$ $\%$.

\section{References}

[1] G. Fang, and L. Jun, "Selective separation of silica from a siliceous-calcareous phosphate rock," Mining Science and Technology, China, vol. 21, no. 1, pp. 135-139, 2011.

[2] R. D. Rogers, and Wolfram, J. H., In Mineral Bioprocessing, R.W. Smith and M. Misra, eds., The Minerals, Metals and Materials Society. Warrendale, PA, 1991, pp. 219-232.

[3] P. Somasundaran, and L. Zhang, "Role of surface chemistry of phosphate in its beneficiation," In: Zhang, P., ElShall, H. and Wiegel, R. eds., Beneficiation of phosphates: Advances in research and practice, SME, Co, USA, 1999, pp. 141-1154.

[4] M. K. Y. Rao, and P. Somasundaran, "Bio-modification of mineral surfaces and flotation," In: Flotation Science and Engineering, ed. K. A. Matis, Chapter 17, 1995, pp. 455-472.

[5] M. K. Y. Rao, P. Somasundaran, K. M. Schilling, B. Carson, and K. P. Ananthapadmanabhan, "Bacterial adhesion onto apatite minerals electrokinetic aspects," Colloids and Surfaces, vol. 79, pp. 293-300, 1993.

[6] M. K. Y. Rao, K. A. Natarajan, P. Somasundaran, Minerals and Metallurgical Processing, vol. 9, pp. 95, 1992.

[7] M. A. Abdel-Khalek, "Separation of dolomite from phosphate minerals by flotation with a new amphoteric surfactant as collector," Transactions of the Institution of Mining and Metallurgy, Section C, vol. 110, pp. 89-93, 2001.

[8] N. A. Abdel-Khalek, and S. Farrah, "Surface modification for advancing separationprocesses and environment protection," US-Egypt joint project, Academy of Science Research \&Technology, Cairo, Egypt, 2004.

[9] I. J. Anazia, and J. Hanna, "New flotation approach for carbonate phosphate separation," Minerals and Metallurgical Processing, pp. 196-202, 1987.

[10] A. M. El-Mahdy, S. E. El-Mofty, N. A. Abdel-Khalek, and M. A. Abdel-Khalek, "The Role of Amphoteric Collector in Improving Flotation of Dolomitic Phosphates of Sedimentary Origin," 2003.

[11] D. T. Shaw, "Introduction to colloid and interface science," Butter worth Heinemann. Oxford 4 Ed, 1992.

[12] P. R. Elizabeth, S. Miguel, M. B. Mar1'a, and A. S. Luis, "Isolation and characterization of mineral phosphatesolubilizing bacteria naturally colonizing a limonitic crust in the south-eastern Venezuelan region," Soil Biolo \& Bioch., vol. 39, pp. 2905-2914, 2007.

[13] Herschel series Instruction Manual 6300-type A, 1998.

[14] D. W. Fuerstenau, Fine Particle Flotation. In Fine Particles Processing, P. Somasundaran, ed. New York: SME / AIP, P. 669, 1980.

[15] M. A. El-Mahdy, "Bio-flotation of dolometic phosphate of sedimentary origin," Mining Engineering Dept., Faculty of engineering, Cairo University, Cairo, Egypt, 2004. 
[16] N. A. Abdel-Khalek, and S. Farrah, "Surface modification for advancing separation processes and environment protection," US-Egypt joint project, Academy of Science Research \& Technology, Cairo, Egypt, 2004.

[17] N. A. Abdel-Khalek, and H. Rao, "Sephosphorization of iron ores," Egyptian-Sweden joint project, 2012.

[18] C. M. Boice, "Selective adsorption and surface modification of apatite and dolomite by microorganisms for the advancement of the phosphate flotation process," M.S. Thesis, University of Florida, Gainesville, Fl, USA, 2000.

[19] M. Misra, S. Chen, R. W. Smith, and A. M. Raichur, "Miner. Metall. Process," pp. 10-170, 1993.

[20] M. Misra, and R. W. Smith, "Mineral bio-processing and the future," Miner. Eng., vol. 4, no. 7-11, pp. 1127-1141, 1991.

[21] N. Ohmura, K. Kitamura, and H. Saiki, Appl. Environ. Microbiol., vol. 59, p. 4044, 1993.

[22] A. Raichur, M. Misra, M. K. Bukka, and R. W. Smith, "Flocculation and flotation of coal by adhesion of hydrophic Mycobacterium Phle," Colloids and surfaces B., Biointerfaces, vol. 8, pp. 13-24, 1996.

[23] A. M. Raichur, M. Misra, and R. W. Smith, "Coal Prepar,” pp. 16-51, 1995.

[24] R. W. Smith, and M. Mishra, "Recent development in the bioprocessing of minerals," Miner. Process. Extract. Metall. Review, vol. 12, pp. 37-60, 1993.

[25] R. W.Smith, M. Misra, and J. Dubel, "Mineral bio-processing and the future," Miner. Eng., vol. 4, no. 7-11, pp. 1127-1141, 1991.

[26] J. A. Solari, G. Huerta, B. Escobar, T. Vargas, R. B. Ohlbaum, and J. Rubio, Coll. Surf., vol. 69, p.159, 1992.

[27] A. M. Raichur, M. Misra, S. A. Davis, and R. W. Smith, "Miner. Metall. Process," pp. 14-22, 1997.

[28] X. P. Zheng, R. W. Smith, R. K. Mehta, M. Misra, and A. M. Raichur, "Miner. Metall. Process,” pp. 15-52, 1998.

[29] I. C. Hancock, "Microbial cell surface architecture," Microbial Cell Surface Analysis, Mozes, N., Handley, P. S. eds., VCH, New York, 1991, pp. 22-59.

[30] N. Deo, and K. A. Natarajan, "Surface modification and biobeneficiation of some oxide minerals using bacillus polymyxa," Miner. Metall. Process., pp. 32-39, 1997. 